\title{
THE IDENTITY OF HADENA HAUSTA GROTE (NOCTUIDAE, LEPIDOPTERA)*
}

\author{
By Dale F. Schweitzer \\ Department of Entomology, \\ Museum of Comparative Zoology, \\ Harvard University, \\ Cambridge, Massachusetts 02138
}

Hadena hausta Grote 1882 was described from a single male from Kittery Point, Maine. Since that time this taxon has been largely ignored. Hampson (1908) sank H. hausta as a synonym of Miana semicana Walker, 1865. McDunnough (1938) and Forbes (1954) followed this placement. Franclemont and Todd (1983) listed both of these taxa as separate species, but their checklist format does not indicate the basis for this decision. Hampson and all of these subsequent authors placed both taxa in Oligia. Since Hampson based his interpretation of $\boldsymbol{H}$. semicana on the type, I accept it as correct. Also, he illustrates this taxon (Plate CXVIII, fig. 3) and his figure seems to match the description of Oligia semicana given by Forbes (1954).

While I was curating the Noctuidae in the collection of the Museum of Comparative Zoology, I located a specimen labelled as the type of Hadena hausta, (M.C.Z. type 1838) along with an accompanying genitalia slide (\#M.C.Z. 477). This specimen (Fig. 1) agrees with the original description and the collection data given in the description match those on the specimen. Thus this appears to be an authentic Holotype. It is not conspecific with the specimen figured by Hampson.

$O$. hausta is somewhat browner than $O$. semicana and differs in having a prominent black dash or wedge in the fold of the forewing much like that present on $O$. exhausta (J. B. Smith), but thicker and less sharply defined. Hampson's figure also seems to indicate a distinctly whitish antemedian line on $O$. semicana. This line has at most some white in its posterior half on $O$. hausta and it is much more evenly curved on the latter species. From $O$. exhausta, $O$. hausta can be separated by its browner color and whiter reniform,

\footnotetext{
*Manuscript received by' the editor March 26, 1984.
} 


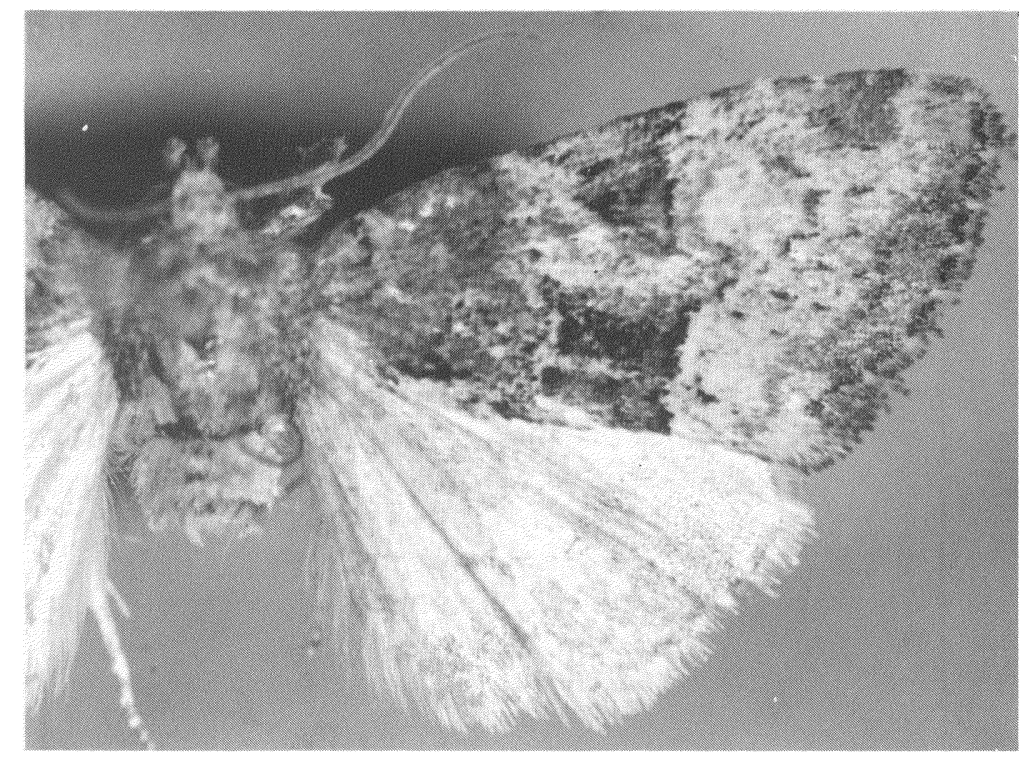

Fig. 1. Holotype of Hadena hausta Grote. Actual length of primary is $10.6 \mathrm{~mm}$.

perhaps most reliably by the lack of an anal dash beyond the postmedian line, and by the fact that the space between the reniform and the postmedian line is at least partially of the pale color that dominates the subterminal space. The space between the reniform and postmedian line is concolorous with the rest of the median area on $O$. exhausta. O. crytora (Franclemont), O. tonsa (Grote) and $O$. semicana agree with $O$. hausta on this character. The posterior end of the reniform touches the postmedian line on all four $O$. hausta before me, but this is the case on only five of 35 O. exhausta examined.

Oligia hausta is apparently rare in collections. The fact that Forbes did not regard it as distinct suggests that he was not familiar with it. Besides the type, which is dated 11 July 1882, there are two other specimens in the MCZ collection from Peggy's Cove and Digby, Halifax Co., Nova Scotia, 11 and 14 July 1953, leg. D. C. Ferguson. I have another on loan from Scott Smedley who collected it at the Wellfleet Bay Audubon Sanctuary on Cape Cod, Massachusetts, 18-19 June 1983 in a mosaic of salt and freshwater wetlands. He reports taking another on $22-24$ June. These will be 
deposited in the Cape Cod Museum of Natural History, in Brewster. All specimens seen are males.

Mark Mello has a specimen of one of the two taxa that commonly pass for $O$. semicana in New England from the Wellfleet site. It differs from Hampson's figure in that there is no prominent antemedian line and the entire forewing inside the postmedian line is rather uniform dark gray, except for the paler reniform.

The differences in maculation of the forewing between $O$. hausta and the other species in the exhausta-semicana section of Oligia seem sufficient to justify treating $O$. hausta as a valid species as was done by Franclemont and Todd. This species seems to combine characters of the immediate semicana group and the distinctive $O$. exhausta.

\section{Lithrature Cited}

Franclemont, J. G. and E. L. TODd

1883. In Hodges, R. W. (ed.f), Check list of Lepidoptera of America north of Mexico. E. W. Classey, Ltd., Farington, Oxfordshire, England. 248 pages.

Forbes, W. T. M.

1954. The Lepidiptera of New York and neighboring states, part 3, Noctuidae. Mem. 274, Cornell University Experiment Station.

Grote, A. R.

1882. New species and notes on structures of moths and genera. Can. Ent. 14:214

HAMPSON, G. F.

1908. Catalogue of the Lepidoptera Phalaenae in the British Museum, vol. 7. British Museum (Natural History), London.

MCDUNNOUGH, J. H.

1938. Check list of the Lepidoptera of Canada and the United States of America, part 1, the Macrolepidoptera. Mem. Southern Calif. Acad. Sci., 272 pages. 

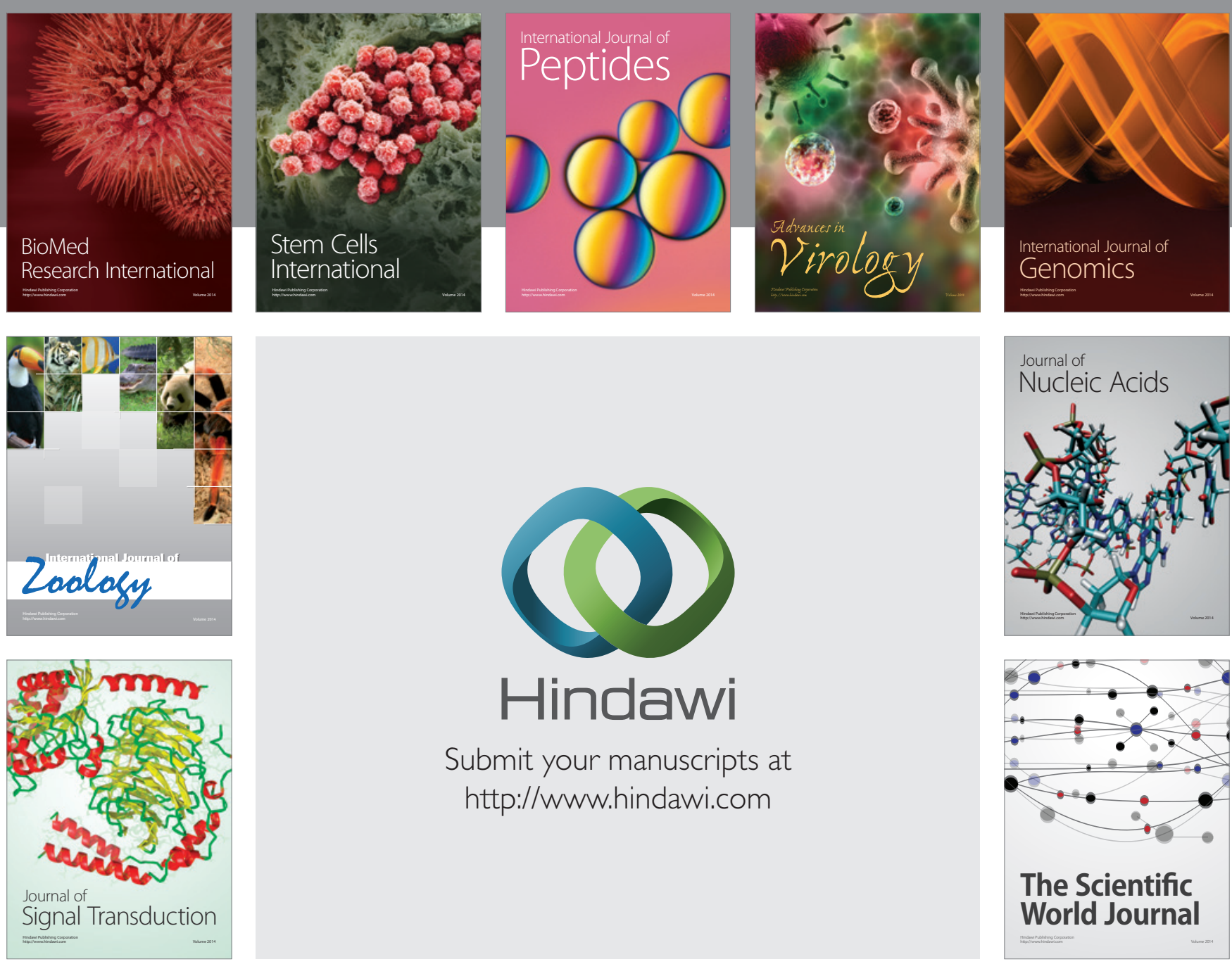

Submit your manuscripts at

http://www.hindawi.com
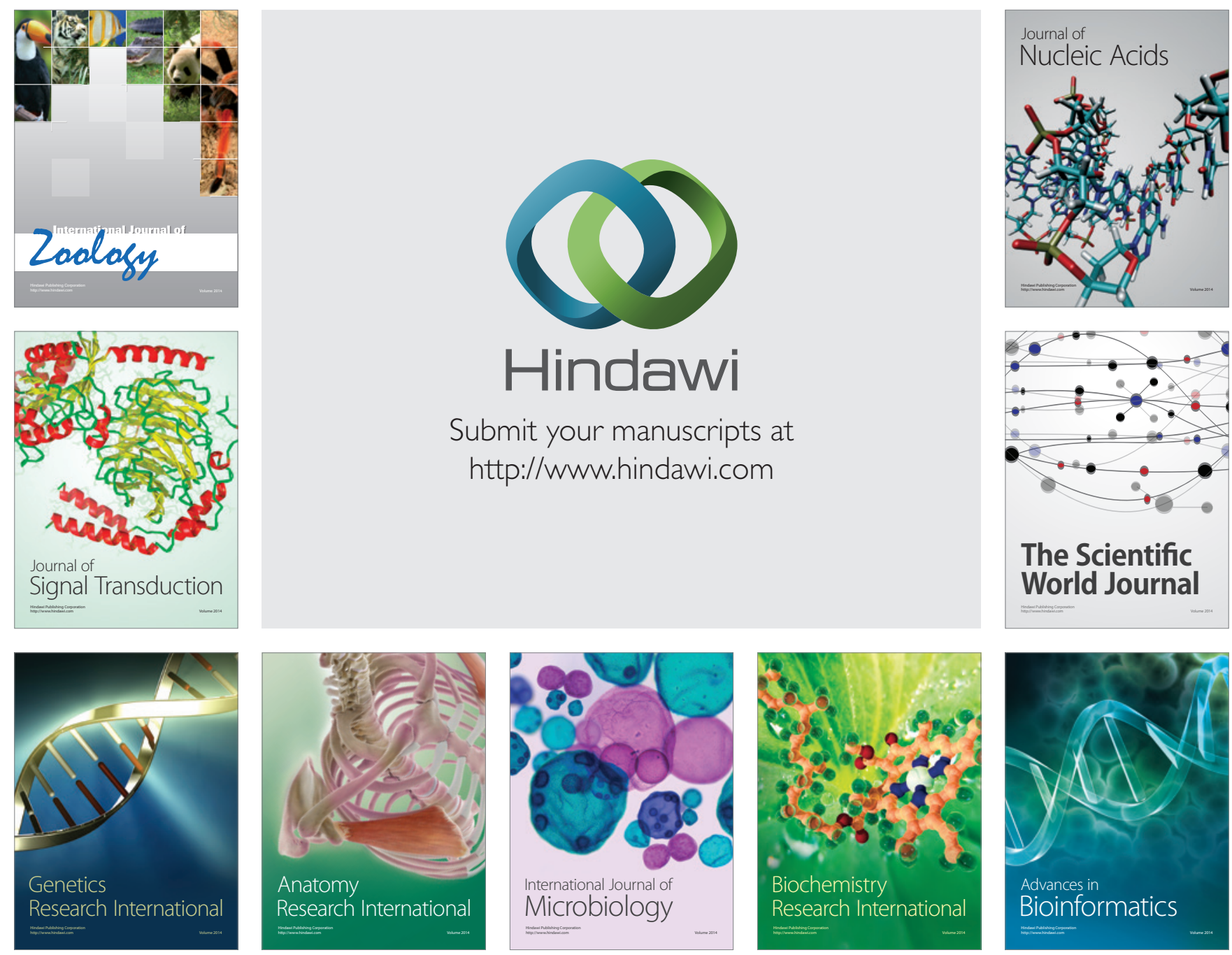

The Scientific World Journal
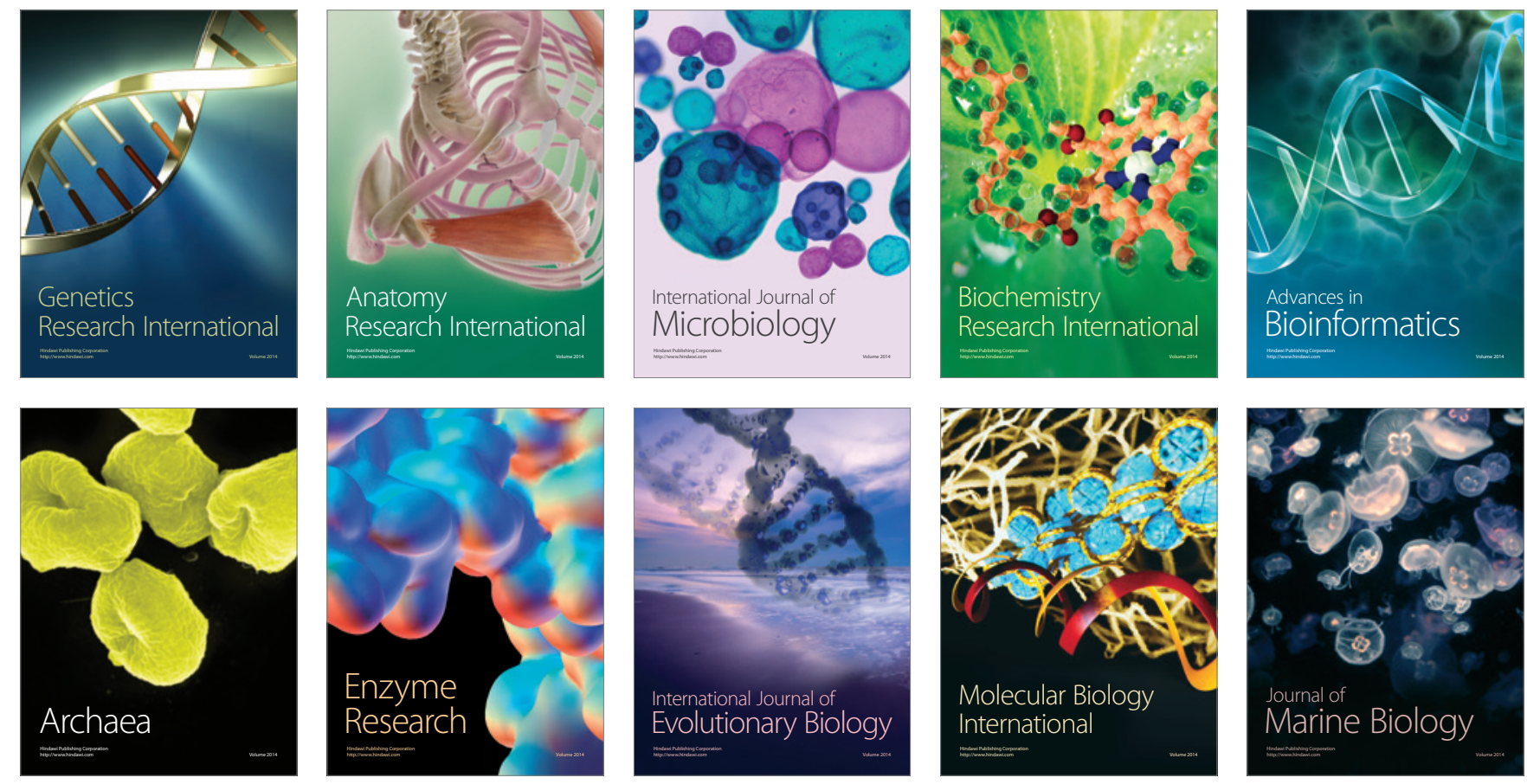